\title{
Replies to critics, European Journal of Pragmatism and American Philosophies
}

Roberto Frega

\section{(2) OpenEdition \\ 1 Journals}

\section{Electronic version}

URL: http://journals.openedition.org/ejpap/1996

DOI: 10.4000/ejpap.1996

ISSN: 2036-4091

\section{Publisher}

Associazione Pragma

\section{Electronic reference}

Roberto Frega, «Replies to critics, European Journal of Pragmatism and American Philosophies », European Journal of Pragmatism and American Philosophy [Online], XII-1 | 2020, Online since 16 June 2020, connection on 26 June 2020. URL : http://journals.openedition.org/ejpap/1996 ; DOI : https:// doi.org/10.4000/ejpap.1996

This text was automatically generated on 26 June 2020 .

\section{c) (i) $९$}

Author retains copyright and grants the European Journal of Pragmatism and American Philosophy right of first publication with the work simultaneously licensed under a Creative Commons AttributionNonCommercial-NoDerivatives 4.0 International License. 


\title{
Replies to critics, European Journal of Pragmatism and American Philosophies
}

\author{
Roberto Frega
}

1 First of all, I warmly thank Matteo Santarelli for having put the symposia together, and Matthew Festenstein, Torjus Midtgarden, and Ed Quish for having accepted his invitation. Once a book is published one has the tendency to let it behind and jump to a new project. Yet this is the time when critical distance finally comes, and one sees better the blind spots and limitations of one's own project. To that extent, engaging with alerted and critical readers is the best opportunity one has to grasp in a more comprehensive way one' own undertaking, for the better, and for the worse.

2 I see this book as the first step of a broader intellectual attempt - the renewal of the democratic project itself. As a consequence, the book wasn't even in press that I was already working at a series of articles where some of the topic that could not find sufficient discussion in the book were addressed. Among them, I wish to mention a piece on the social ontology of democracy, ${ }^{1}$ two on the renewal of social-democracy, ${ }^{2}$ and a series of five papers on workplace democracy. ${ }^{3}$ Compared to the book, these articles are much less dependent on the intellectual resources of a specific philosophical tradition and are more, so to say, intellectually "freestanding." If I mention this, this is only to make more explicit that this book was just a beginning. More than deploying the entire plot, I was particularly committed to showing the relevance to the project of a philosophical tradition - American Pragmatism - to which study I have devoted the largest part of my academic career so far.

In what follows I will briefly take on my critics' comments in their publication order in this symposia.

4 Festenstein focuses the first row of critical comments on an apparent paradox. He contends that an all-encompassing application of the democratic norm to social life would fail to appreciate the democratic importance of associations which are organized in non-democratic ways. He quotes pressure groups, but also political parties and the 
army fall into this group. He sees them as anti-democratic in their internal organization, yet necessary for the functioning of democracy as a system. This is, indeed, a topic I discuss in Chapter 7, where I take on Mark Warren's theory of democracy and associations and introduce the notion of associational relations.

5 I think Festenstein is right in raising the question of a possible tension between the micro and the macro dimensions of democracy, yet I am persuaded that the tension does not give rise to a paradox, since my claimed priority of democracy as a form of society has the status of a prima facie claim. Social organizations such as pressure groups, churches, and political parties have a specific function within a democratic polity. At the same time, their internal organization matters for democracy (p. 267). On the one hand, there is the question of the specific democratizing function of a given type of association, no matter how it is organized. This is the system or macro level. On the other hand, there is the question of the democratizing meaning of internal patterns of organization. This is the micro level.

6 By replacing the idea of the democratizing function of associations as such with that of the democratizing function of the associational principle, my contention is that associations that have a democratic function at system level ought still to comply, at least prima facie, with the democratic norm as a principle of internal organization. These two imperatives, the functional and the expressive, need to be identified, disentangled, and maximized as much as possible. Maximizing the functional while improving the expressive would boost the democratic quality of our societies to a much higher level. In this sense, I do not see my contention to be utopian, quite the contrary.

7 As a matter of fact, not all pressure groups, nor all parties or churches are organized in the same manner, and the same holds for armies. Even within associations of this type we can distinguish between more democratic and less democratic organizational patterns, and the three principles of (a) relational parity, (b) inclusive authority, and (c) social involvement are there to help us do this discrimination. Armies can hire or exclude women, include or discriminate homosexuals, exercise authority in violent or deliberative ways, and all this matters infinitely for the democratic quality of a society.

8 As Festenstein has written in his comments, a pressure group such as Greenpeace is neither inclusive nor egalitarian yet it has democratic relevance. My point is that its usefulness at system level should not be a justification for tolerating an undemocratic form of internal organization. Greenpeace could continue to fulfill its democratizing function while adopting more inclusive, less inegalitarian, and less hierarchical organizational patterns. If this can be done without imperiling its functional contribution to democracy, then there is a duty to improve its democratic internal organization. If not, then we face a conflict between two democratic imperatives which would have to be settled. I do not think this tension can be removed, because any form of human organization faces at the same time internal and external constraints, it must comply with input- as well as with output-legitimacy requirements. Democracy, in other terms, is successful only if it delivers. Efficiency according to my view is built into the conceptual and sociological fabric of democracy, it is not its antithesis (see ch. 8 on this).

9 The second question Festenstein raises in his commentary is that of the possible incompatibility of my account of democracy with pluralism. That is, with the idea that many people may simply not share my views about inclusion and authority. 
10 Festenstein's concern stems, I fear, from with my unwillingness to provide a justification of democracy and its legitimacy, so that I may appear to have simply dressed the list of my preferred normative principles, expecting others to share my views.

11 This is a major point of contention, because I actually do not share political theory's overconcern with justification and legitimacy. My sense is that political theory's infatuation for them has done a bad service to the profession and to the larger society, since we have lost familiarity with other major and fundamental academic practices, one of which consists precisely in articulating complex normative meanings, as we do when we reinterpret notions and traditions. In my book, I take it as an uncontroversial starting point that democracy has provided the social and political horizon of Western societies for the last two centuries. I do not see much need, today, to engage in complex theoretical justifications of this point. Yet I think that the meaning of the democratic project which sets our societal horizon remains insufficiently spelled out. We have had, in the past, a thriving debate about the supposed priority of equality over freedom, or of liberal over socialistic democracy but we have, most of the time, forgotten fraternity, the third normative pillar of the democratic project that saw its birth with the French and American revolutions of the late 18th century.

12 Yet in the last three decades even this kind of debate has mostly been abandoned, and our intellectual energies have been focused on increasingly sophisticated justificatory exercises which are not of much help to understand what does it mean for us European, today, to live in democratic societies. More than another justification of the superiority of democracy over authoritarianism, we need to start thinking again about the manifold meanings of the democratic norm, about its larger societal and economic implications, about how democracy transforms our life opportunities, how it shapes our interactions with our fellow human beings, how it determines our chances and expectations.

13 Festenstein writes that "It is not clear if the aspiration of Frega's wide view is to present a transformed and extended vision of democratic legitimacy or, more generally, of a morally justified form of society." My answer would be that my aspiration is neither of these. If I speak of a democratic project (actually, my original and preferred title, rejected by the publisher), this is precisely because my aspiration is to renew the normative horizon within which we live together, which requires in turn a fresher interpretation of what constitutes this form of life beyond (or below) its protective political shell. That is, the social interactions of which social life consist. The three principles of relational equality, social involvement and inclusive authority simply reformulate the old democratic triad of freedom, equality, and fraternity in a way that I find more helpful to describe how democracy as a norm informs our everyday life. Yet the basic intuition is nothing new. It is, simply, what democracy has been consisting of for more than two centuries, even though, perhaps, only in a still limited part of the world.

14 Torjus Midtgarden takes a more historically oriented route to my book, challenging some of the intellectual associations on which I rely to broach my social ontological reading of Dewey's idea of democracy as a way of life.

Midtgarden sees an opposition between two traditions of social ontology, one that goes from Durkheim to Goffman and Garfinkel, committed to a "sui generis" understanding of the social, and one that is more distinctively Deweyan, and which construes the 
social as "inclusive," rather than sui generis. Implicitly, since I rely on both conceptions, Midtgarden points to a contradiction in my approach. How can I rely on authors which, if he is correct, endorse incompatible views of the social?

Midtgarden suggests a way out of this impasse through a reconceptualization of my triadic social ontology, so as to blend the sui generis with the inclusive approaches. This suggestion goes against the grain of my own attempt to take stock of the two conceptions by keeping the social and the political disjoined, rather than integrating the political dimension into the social ontology. In other terms, where I see Dewey's conception of the public as part of his political, rather than social theory, Midtgarden urges me to overcome this distinction and bring Dewey's notion of public within my social ontology, besides habits, patterns, and forms.

Midtgarden is right in saying that I fully subscribe to Garfinkel and Goffman's view of the social as sui generis, a position I discuss at length in the book. ${ }^{4}$ Indeed, I take social interactionism broadly construed to be the most promising account on which a social theory of democracy can be built. I am also aware that on its own social interactionism is inadequate to fully sustain a political view of democracy, since social interactionism lacks a satisfying account of the genesis of institutions, as well as a theory of the distinctive function of politics as a specific system. Yet, as scholars such as Anthony Giddens have shown, it is nevertheless possible to build an institutional perspective on a social interactionist basis, which is exactly what I try to do, by relying on the pragmatist tradition of democratic experimentalism, that I interpret as a theory of social and political institutions, and by developing a theory of public activation based, in part, on Dewey's notion of public.

18 I am sympathetic with Midtgarden's reservations about the fruitfulness of associating Dewey with the Human Ecology movement, but I think that the bulk of my argument is not really affected by the divergences he points at, since what really matters here are the proximities on which a common view can be construed, the differences notwithstanding.

19 I disagree, however with his idea that the notion of habit is in tension with those of patterns of interaction and forms of organization. Indeed, if one looks at Dewey's theory of habits as it is developed in Human Nature and Conduct, their stabilizing function is clearly attested. Even though Dewey does not formulate things in this way, the idea is clearly present that whereas impulses bring disruption and novelty into action, habit is what provides action with regularity, predictability, stability. My point is that habits achieves at individual level what patterns and forms achieve at the aggregate social level. That is, they impose upon the unpredictability of human interactions some form of stability.

In my account of the social ontology of democracy I have so far not considered the role of emotions and intelligence, which is admittedly a weakness, and I welcome Midtgarden's criticism as an invitation to integrate these perspectives in my future publications on this topic, which I will certainly do. This is perhaps one of the least satisfying implications of my way of distinguishing and articulating the social and the political dimension of democracy, since this theoretical move inclines me somehow to overemphasize the stabilizing dimension of sociality, while confining the active and transformative to the political dimension, which is of course a too sketchy account of reality. There is a price to pay in sharply separating the social from the political, and Midtgarden reminds this with clarity. But there are also advantages, the most 
important being the possibility to make fully visible the social structuring of democracy, so as to provide a solid sociological description of what Dewey named a "way of life" and Claude Lefort a "form of society."

21 In his comments, Ed Quish suggests that my move towards a social account of democracy ought to be radicalized even further by taking into greater account the implications for democracy of economic inequality and organized political conflict. In so doing, he criticizes me for an overemphasis on the formal preconditions for the existence of democracy. This is a very important argument, since it points to a broader and crucial factor of disagreement or misunderstanding between pragmatism and radical/critical traditions in contemporary political theory.

There exist two overall general strategies to resist the liberal reduction of democracy to a political regime for the protection of individual rights and liberties. On the one hand, the one usually associated with the name of Karl Marx, which emphasizes the economic underpinnings of any political association, and pointing toward a potential contradiction, or at least tension, between capitalism and democracy. On the other hand, the one which focuses on the social constitution of human identity, and which emphasizes democracy's revolutionary transformation of patterns of social interaction. In my book I side decidedly with the second strategy, not because I do not consider the first relevant, but because the second is a much less traveled road, and one which needs to be explored in greater depth. So Quish is at the same time right and wrong in criticizing me for neglecting the first strategy.

This answer is of course acceptable only to a point, since it does not say whether the two strategies can be really combined, or whether supporters of one see the other as a mere reflex of the one they consider most important. It is well known, to make only an example, that for some strands of Marxism the idea that democracy can cure the ills of capitalism merely amounts to false consciousness.

Quish and I share the idea, closer to the pragmatist tradition, that the two strategies are and indeed ought to be integrated. He is then right to remind that even for Dewey economic inequality beyond a certain threshold represents an internal limitation to the deployment of the democratic project itself, one that is conceptually and causally irreducible to the social factors on which I focus.

There are, however, two aspects Quish does not seem to consider. The first is that, contrary to what he seems to think, the plight of formal inequality in social relationships, not to mention that of systematic social exclusion and of an antidemocratic exercise of authority are not a thing of the past, but continue to plague democratic societies even today. One has only to consider that many democracies established universal suffrage only after WWII, that formal racial discrimination was legal in the US till the late ' 60 , and that authority in most workplaces, bureaucracies, and educational institutions continue to be exercised in fully non-democratic ways even today. These social factors continue to stand in the way of the democratic project, and their damaging consequences will continue to remain underestimated if our theoretical frameworks are dominated by a focus on either the deficits of formal political institutions, or economic exploitation and inequality.

The second aspect concerns the complex history of the relationships between capitalism and democracy, particularly after WWII, when a successful compromise allowed most European states to build generous welfare systems that deeply improved overall economic, social, sanitary, educational, cultural conditions of the largest part of 
the population. There can be disagreement about the extent to which this process has been satisfying, and there is for sure a need to consider the more recent but steep increase in inequality nearly everywhere. But I think that the deep materialistic presuppositions of a narrative of the crisis of democracy based on economic inequality misses a central dimension of the democratic project, which is that of the human emancipation made possible by a thorough transformation of patterns of social interaction. Economic inequality is certainly a powerful threat to this project, but the project is larger than that, and cannot stop nor mostly focus on the economic dimension.

In relation to this, I am happy Quish brings forth the question of workplace democracy, since after the publication of the book I have devoted a series of papers to showing the implications of my wide view of democracy to reconsider the functioning of the workplace as a basic social institution, since I consider the democratization of workplaces a crucial step in the advancement of the democratic project.

Yet, even with reference to workplace democracy, I would not consider economic inequality or exploitation to be the core topic to address. Or, at least, I would contend that the democratization of the workplace requires much more than reducing economic inequality, sharing ownership, or renewing the role of trade unions. Even at the level of the workplace, what the democratic norm requires is a revolution in patterns of social interaction which cannot be confined to reforms in decision-making mechanisms, as supporters of workplace democracy contend most of the time. Saying this is not enough does not mean this is not important, quite the contrary. But it means that our discussion of workplace democracy is significantly impoverished when we understand democratic deficit in the workplace in the terms of a theory of formal political government, or reduce them to a chapter in the critique of capitalism.

Quish's last remark is that I neglected the role of political parties. Whilst I cannot deny this, I think he is mistaken in reducing non-party collective activation on which my discussion focuses to forms of 'private volition'. Indeed, what I wanted to emphasize in my account was precisely the political relevance of activities usually not categorized as such. Particularly in my criticism of Jürgen Habermas' theory of the public sphere, my interest was in bringing to the fore the political relevance of social practices through which collective goods can be achieved without any form of formal political activation such as that which is achieved through political parties.

30 My point is not that parties are not relevant anymore, but that major political consequences are produced also in ways which do not pass through forms of public mediation as required by theories of the public sphere.

31 The declining confidence in parties and in the other formal political institutions is under our eyes. Whilst it is true that we ought to do the best we can for renewing these institutions as agents of the public, there is also an alternative route which is inscribed in the pragmatist tradition and which is systematically neglected in contemporary debates. This route passes through the self-activation of the public through practices that cross the boundary between the public and the private, the political and the social, the political and the economic. Because of their hybrid nature, these practices are systematically disregarded by political theory, and often criticized as forms of privatization, or commodification. My point is that Deweyan pragmatism helps us take a fresher and new look to this practices, a look that reveals their democratizing potential. 


\section{BIBLIOGRAPHY}

FREGA Roberto, (unpublished manuscript), Has Social Democracy Run Out of Steam?

FREGA Roberto, (2019), “The Social Ontology of Democracy," Journal of Social Ontology, 4 (2),157-85.

FREGA Roberto, (2020), "Il populismo come l'altro della social-democrazia," in Antonio Masala (ed.), L'eà dei pupulismi, Roma, Carocci.

FREGA Roberto, (2021a), "Firms as Coalitions of Democratic Cultures: Towards an Organizational Theory of Workplace Democracy," Critical Review of International Social and Political Philosophy.

FREGA Roberto, (2021b), "Pragmatist Ontology From Habits to Patterns of Social Interaction," in Italo Testa \& Fausto Caruana (eds.), Habit: Pragmatist Approaches from Cognitive Neurosciences to Social Sciences, Cambridge, Cambridge University Press.

FREGA Roberto, HERzog Lisa \& Christopher nEUHAUSER, (2019), "Workplace Democracy - The Recent Debate," Philosophy Compass, 14 (4).

FREGA Roberto, HERZog Lisa \& Christopher nEUHAUSER, (2020a), “Against Analogy: Why Analogical Arguments in Support of Workplace Democracy Must Fail," Democratic Theory, 7 (1), 1-26.

FREGA Roberto, HERzog Lisa \& Christopher neUHAUSER, (2020b), "Democratic Patterns of Interaction as a Norm for the Workplace," Journal of Social Philosophy, 5 (1), 27-53.

FREGA Roberto, HERZOG Lisa \& Christopher NEUHAUSER, (forth.), "Workplace Democracy 2.0:

Completing the Picture," Business Ethics Quarterly.

\section{NOTES}

1. Frega 2019.

2. Frega 2020; and Frega. (unpublished manuscript).

3. Frega, Herzog \& Neuhauser (2019; 2020a; 2020b; forth.), Frega 2021a.

4. But see also Frega 2021b, where I update my view of social interactions by distinguishing between "bare social interactions" and patterns of interaction.

\section{AUTHOR}

\section{ROBERTO FREGA}

Centre Marc Bloch, Berlin

fregarob[at]gmail.com 